\title{
Writer and Process: A Success Story Waiting to Happen ${ }^{1}$
}

\author{
Anna Carolina Peñaloza Rallón \\ anna.penaloza@uptc.edu.co
}

It is time to face the facts. Every day we are asked to write more and more in English. Our academic existence is dependent on whether we can publish in English or perish (Mauranen, Pérez-Llantada, \& Swales, 2010). English has become the lingua franca of science and knowledge, but what happens when the structures and rules of standard Academic Writing seem to be against us? Well, writers learn to adapt. We use translators, copy model structures, look for outside help, hire proofreaders, and talk to teachers.

Despite our efforts, only a few writers become successful. What if we could find a solution within our own context? What if these successful writers had a secret to share with the rest of us? After all, every individual has been through a "writing process", a series of events that have shaped the writer. By looking at the events that made successful writers who they are, we could understand how to better improve teaching practices in writing, develop efficient writing strategies, and promote individual writing styles all within our own context.

I recently interviewed three academically celebrated women at our university. These women had published in national and international journals, and they seemed independent in everything they wrote from choosing the topic to how to structure their ideas. On occasion, they hired a proofreader, but they had done most of the work. I wanted to know about the central, or significant, events that had marked their writing process. What I found was that each writer had lived the writing process differently. Their central events showed a network of causality, where one event caused the next one. In the women's stories, I noticed that even if an event had finished, it continued to show up and interconnect with other central events, beliefs, reasoning, and decision-making processes.

\footnotetext{
${ }^{1}$ Reflective essay.
} 
One of the key aspects that appeared in each central event was the presence of an agent. An agent can be another person or entity that helps shape the story. For these women, it was their teachers, parents, laboratory directors, and journal evaluators. Agents play a significant role in the writing process. Successful outcomes in central events usually had a positive interaction between the agent and the writer. A word of encouragement, a helpful tutoring session, or an invitation to publish had profound implications on the writer's confidence and will to carry on. So, we can see that our role as parents, teachers, and evaluators can shape better writers. In the English classroom, we can begin by promoting individuality. Instead of marking a paper for all of its errors, we can look at the writer's efforts and award him or her for taking that first step. For example, many of my students' best work has come from questioning the structure I initially taught them. They might start with an unexpected hook, or they might put an existential moral in the middle of a story as a personal reflection. Individual tutoring sessions can also build a rapport with our students. Constructive and personal feedback are a must when grading and checking work. Our active and constant participation in our students' process is a solution to helping writers become successful.

Another key aspect in the women's stories was their uniqueness. No two stories were the same. Our students also have their own writing process shaped by cultural factors, such as gender, age, status, and the context itself. Yet, we seem to stress a standard writing process that many of us probably do not follow. After all, how many of us prewrite, draft, edit, and write when our paper is due tomorrow? I am not here to criticize the work of Hyland (2003) or Hayes and Flower (1980), among others. These writing processes are a wonderful way to plan out and structure our work, but we need to look at the realities within our context. Do we really have enough time in our classes to promote all the writing steps? Will our students find these steps meaningful without the help of more relevant strategies? I believe that we can merge parts of the writing process with other student-centered language learning strategies in the classroom. For example, we can have biology students read for the main idea in an article about glyphosate. Then, they can summarize the idea, paraphrase the findings, and directly cite the discussion as part of the prewriting process. Therefore, the content and strategies should be based on the students' needs rather than a direct adoption of standardized practices. This means that the curriculum and content will also be co-constructed directly with the student, either through surveys or student feedback throughout the course. In doing so, we provide students with the 
tools they need to become independent writers.

The three academically celebrated women enlightened me about the uniqueness of the writer. Apart from having different agents and processes, they also allowed me to understand that we are all exceptional. Our ability to adapt and transform is outstanding. Though we are shaped by the context and interactions with others, we also have the power of change. The constant revolutions and interconnections of our experiences touch every fiber of our writing style. As one of the women writers that I interviewed mentioned, uno tiene que posicionarse, y uno toma una posición y esa posición depende de lo que yo soy entonces usted me lee así porque así soy yo, no va a leer a otra persona porque no fue otra persona la que escribió, fui yo y así como está allí, así soy yo. [you have to position yourself, and you take on a position, and that position depends on who I am. So, you read me like this because that is who I am, you are not reading another person because it was I who wrote, it was me, and just like it is, that is me.]

(Juliana, Interview)

What Juliana stated is the very reason we study literature and praise the authors who marked literary movements. What would the world be like if Edgar Allan Poe had stayed in the colonial period, or if Emily Dickinson had written about marriage rather than her inner pain? Within every classroom we have a resource of talented writers, each with a voice and story to tell. As teachers, we need to start looking at the individual's writing style as a source of innovation and appropriation of the language. It might not look like the next masterpiece at first, but with encouragement and strategy, we can help our students make the change from standardization to a language of their own. As Maya Angelou once said, "I believe that the most important single thing, beyond discipline and creativity is daring to dare." So, let's dare to innovate. Let's dare to make a change. More importantly, let's dare to be the agents our students so desperately need to become successful writers. 


\title{
References
}

Hayes, J. R., \& Flower, L. (1980). Identifying the organization of writing processes. In L.W. Gregg \& E.R. Steinberg (Eds.), Cognitive processes in writing (pp. 3-30). Hillsdale, NJ: Erlbaum.

Hyland, K. (2003). Second language writing. New York, NY: Cambridge University Press.

Mauranen, A., Pérez-Llantada, C., \& Swales, J. M. (2010). Academic Englishes: A standardized knowledge? In A. Kirkpatrick (Ed.), The Routledge Handbook of World Englishes (pp. 634-652). London, UK: Routledge

\section{How to cite this essay:}

Peñaloza, A. C. (2019). Writer and process: A success story waiting to happen. Enletawa Journal, 12(1), 90-93.

\begin{abstract}
About the author:
Anna Carolina Peñaloza Rallón is a Master's in Language Teaching candidate at the Universidad Pedagógica y Tecnológica de Colombia (UPTC). She holds a B.S. in Environmental Science from the University of Arizona, Tucson, Arizona. Anna is an English teacher and editorial assistant at the Universidad Pedagógica y Tecnológica de Colombia, Tunja, Colombia.
\end{abstract}

